Volume 1 Nomor 2, Agustus 2016, halaman 70-82

\title{
PEMBELAJARAN BERMUATAN DISPOSISI MATEMATIKA PADA KELAS X PROGRAM IPS
}

\author{
Denni Ismunandar \\ Universitas Wiralodra, denniismunandar@gmail.com
}

\begin{abstract}
ABSTRAK
Tujuan dari penelitian ini adalah mengetahui keefektifan model Problem Based Learning (PBL) bermuatan disposisi matematik dan keterampilan komunikasi matematik pada kelas $\mathrm{X}$ program IPS. Pemilihan sampel secara acak dan terpilih $X$ IPS 4 sebagai kelas eksperimen dan kelas $X$ IPS 3 sebagai kelas kontrol. Hasil dari penelitian ini adalah terdapat pengaruh yang kuat antara disposisi matematik dan komunikasi matematik dalam meningkatkan kemampuan pemecahan masalah pada siswa. Rata-rata kemampuan pemecahan masalah kelas eksperimen lebih tinggi dari kemampuan pemecahan masalah pada kelas kontrol.

Kata kunci: Problem Based Learning (PBL), disposisi matematik, keterampilan komunikasi.
\end{abstract}

\begin{abstract}
The purpose of this study was to determine the effectiveness of the model of Problem Based Learning (PBL) charged disposition of mathematics and mathematical communication skills in class X IPS program. Selection of a random sample run private and X IPS chosen as an experimental class 4 and class X IPS 3 as the control class. Results from this study is there a strong influence among the disposition mathematics and mathematical communication in improving problem-solving skills in students. On average problem-solving abilities higher than the experimental class problem-solving abilities in the control class.

Keywords: Problem Based Learning (PBL), the disposition of mathematical, communication skills.
\end{abstract}

\section{How to Cite: Ismunandar, D. (2016). Pembelajaran Bermuatan Disposisi Matematika pada Kelas X Program IPS. Mathline: Jurnal Matematika dan Pendidikan Matematika, Vol.1, No.2, 70-82.}

\section{PENDAHULUAN}

Matematika merupakan mata pelajaran yang selalu ada dalam setiap jenjang pendidikan pada tingkat dasar dan menengah. Pada saat pendidikan dasar, pelajaran matematika diberikan sejak saat kelas satu hingga kelas enam. Pelajaran matematika didapatkan selama enam tahun, selanjutnya pada tingkat SMP, pelajaran matematika di dapatkan selama 3 tahun. Namun demikian, ketika masuk ke tingkat SMA, pada semester pertama, nilai matematika siswa kelas $X$ jurusan IPS disalah satu SMA di Indramayu, hasilnya kurang memuaskan. Beberapa penyebabnya adalah siswa kurang mendapatkan 
pembelajaran yang bermakna, siswa belum mampu melakukan proses belajar, siswa belum mampu membaca bahasa matematika, dan lain-lain. Pembelajaran yang bermakna menurut Ausubel (Hudojo, 1988) adalah bila informasi yang akan dipelajari siswa disusun sesuai dengan stuktur kognitif yang dimiliki sehingga siswa dapat mengaitkan informasi barunya dengan stuktur kognitif yang dimilikinya. Pada pembelajaran bermakna ini, peran serta guru sangat mempengaruhi siswa. Karena guru dalam mengajar harus memperhatikan kemampuan kognitif siswa. Dengan pembelajaran bermakna ini, siswa akan selalu mengingat hal yang dilakukannya, kesalahan-kesalahan yang dilakukan dan cara penyelesaian masalah yang benar setelah melalui kesalahan tersebut.

Proses belajar yang baik menurut Robert Gagne (Hudojo, 1988) merupakan proses yang memungkinkan manusia memodifikasi tingkah lakunya secara permanen, sedemikian hingga modifikasi yang sama tidak akan terulang kembali pada situasi yang baru. Belajar terjadi bila individu merespon terhadap stimulus yang datangnya dari luar. Sedangkan kematangan datangnya dalam diri orang itu. Proses belajar yang dikemukakan oleh Robert Gagne tentang perubahan tingkah laku siswa sangat dipengaruhi oleh kemampuan guru dalam membangkitkan motivasi siswa dalam kegiatan belajar. Ketika siswa dapat merubah tingkah lakunya dari belum mencoba menjadi mau mencoba, dari belum mengerjakan menjadi mau mengerjakan, dari belum tahu menjadi tahu. Hal ini akan membuat siswa merubah tingkah laku siswa sehingga siswa menjadi siswa yang belajar tanpa diperintah oleh orang lain.

Kemampuan membaca bahasa matematika juga sangat diperlukan. Menurut Hudojo (1988), bahasa matematika yang disebut juga dengan bahasa logika digunakan untuk komunikasi ilmu. Bahasa logika berkaitan dengan nalar secara sah dilihat dari aspek bentuk argumentasi, terlepas dari isi dan materi. Secara singkat bahasa logika membentuk abstraksi dari materi. Pendapat tersebut berkaitan erat dengan kemampuan membaca peristiwa dalam kehidupan sehari-hari selalu berkaitan dengan matematika. Beberapa penyebab yang lain tidak dibahas oleh peneliti.

Kurang memuaskannya hasil siswa terlihat pada rata- rata nilai ujian semester ganjil kelas X IPS 2 adalah 76,53. Rata- rata nilai ujian semester ganjil kelas X IPS 3 adalah 76,63. Rata- rata nilai ujian semester ganjil kelas X IPS 4 adalah 76,67. Kriteria Ketuntasan Minimum (KKM) SMA adalah 75,00. Walaupun sudah melampaui batas KKM, namun peneliti masih belum puas, karena hasil tersebut masih lebih rendah dari harapan peneliti. 
Peneliti menentukan KKM minimum adalah lebih dari sama dengan 78. Peneliti melakukan identifikasi masalah supaya tidak terjadi hal yang demikian lagi. Oleh sebab itu, peneliti bersama teman sejawat dan guru senior sepakat bahwa trigonometri merupakan materi yang sulit dipahami dan dikuasai oleh siswa. Hal ini juga ditunjukkan dengan hasil ulangan materi trigonometri tahun lalu belum memuaskan.

Peneliti melakukan observasi untuk meyakinkan bahwa materi trigonometri akan diambil untuk penelitian pada semester genap. Peneliti melakukan observasi dengan mengambil sampel acak 30 laki-laki dan 40 perempuan kelas XI IPS. Setelah dilakukan observasi, peneliti memperoleh data bahwa $71,43 \%$ siswa menyatakan materi trigonometri sulit untuk diselesaikan, 85,71\% menyatakan tidak menyukai pelajaran matematika, dan $76 \%$ menyatakan tidak dapat mengungkapkan kembali materi yang telah dipelajari terkait dengan materi trigonometri.

Peneliti menggunakan model pembelajaran Problem Based Learning (PBL) atau pembelajaran berbasis masalah untuk meningkatkan hasil prestasi siswa. Pada penelitian ini, peneliti memfokuskan pada kemampuan pemecahan masalah. Kurikulum yang digunakan dalam pembelajaran saat ini masih berkaitan dengan kurikulum 2013. PBL merupakan salah satu model pembelajaran yang dianjurkan oleh Kemendikbud. Pembelajaran dengan model PBL terbagi menjadi lima fase. Fase pertama adalah orientasi siswa pada masalah. Pada fase ini siswa diberikan masalah. Masalah diberikan dapat berupa gambar, pertanyaan tertulis, maupun pertanyaan lisan. Fase kedua adalah mengorganisasikan siswa. Pada fase ini siswa dibagi menjadi beberapa kelompok. Pada pembagian kelompok ini, peneliti membagi berdasarkan cita-cita siswa yang terbagi menjadi empat kriteria, yaitu: wirausahawan, pegawai, atlet, dan staff ahli (duta besar, desainer, arsitek dll). Fase ketiga adalah membimbing siswa secara Scafolding, siswa diberikan arahan untuk mengerjakan, yaitu hanya diberikan petunjuk saja tanpa memberitahukan jawabannya, pada pertemuan selanjutnya siswa lebih sedikit diberi petunjuk dan akhirnya siswa tidak diberikan petunjuk karena siswa telah menguasai materi. Fase keempat adalah mengembangkan dan menyajikan hasil jawaban siswa ke depan kelas. Siswa menuliskan jawaban di depan kelas dan menerangkan hasilnya kepada teman-teman siswa tersebut. Pada fase ini, keterampilan komunikasi siswa dapat terlihat, siswa yang benar-benar menguasai materi dan siswa yang belum menguasai materi dapat terlihat. Fase kelima adalah analisis dan mengevaluasi proses pemecahan masalah. Pada fase ini guru berperan penting, guru bersama siswa menganalisis 
dan mengevaluasi langkah-langkah penyelesaian. Jika langkah penyelesaian belum tepat, maka guru memberikan langkah penyelesaian secara tepat. Namun jika langkah penyelesaian siswa sudah tepat, maka guru menyimpulkan hasil pembahasan pada saat itu.

Peneliti menggunakan moidel pembelajaran ini karena erat kaitannya dengan sientific learning. Yang dimaksud dengan sientific learning menurut kemendikbud (2013) adalah model pembelajaran yang menggunakan lima langkah pembelajaran, yaitu mengamati, menanya, menalar/ mengasosiasi (menyelidiki), mencoba dan membentuk jejaring (komunikasi). Kelima langkah ini biasa disebut dengan 5M. Melihat kemampuan kognitif siswa masih belum memuaskan, peneliti berusaha meningkatkan kemampuan pemecahan masalah siswa, peneliti memilih kemampuan pemecahan masalah karena menurut peneliti dalam memecahkan masalah berupa soal cerita, siswa masih mengalami kesulitan. Terbukti pada angkatan tahun yang telah lalu nilai tes ulangan harian materi trigonometri masih belum memuaskan. Peneliti memilih keterampilan komunikasi untuk meningkatkan kemampuan pemecahan masalah pada siswa, dengan komunikasi yang lancar dalam mempresentasikan hasil yang telah dibahas atau didiskusikan pada kelompok dapat meningkatkan kemampuan pemecahan masalah. Keterampilan komunikasi siswa dapat dilihat dari beberapa indikator. Beberapa indikatornya menurut NCTM (Elida, 2012) adalah siswa mampu mengekspresikan ide-ide matematika melalui lisan, tulisan dan mempresentasikan secara visual; mendengarkan, berdiskusi, dan memahami masalah serta memvisualisasikannya; dan mampu menggunakan istilah-istilah, notasi matematika dan memodelkan peristiwa kedalam bentuk matematika secara lisan maupun tulisan.Wichelt \& Kearney (2009) berpendapat bahwa dengan memiliki kemampuan komunikasi matematik, siswa dapat memperoleh keuntungan, hal yang dipelajari selaras dengan sesuatu yang siswa pikirkan pada saat pembelajaran, dengan memiliki kemampuan komunikasi matematik, siswa dapat memahami bagaimana berbicara dengan bahasa matematik, sehingga siswa dapat dengan mudah menerima ide materi yang dipelajari.

Keterampilan komunikasi tidak tiba-tiba langsung diperoleh. Keterampilan diperoleh dari rasa menyukai materi yang dipelajari, rasa senang, gairah, rasa ingin tahu yang tinggi, percaya diri dan sebagainya. Menurut Bell (2013), disposisi matematik akan mempengaruhi pembelajaran siswa terutama pada refleksi pada bagian akhir pembelajaran, guru berperan penting dalam proses pembelajaran, memberikan alasan yang tepat dapat membantu siswa mempelajari materi yang diajarkan. Peneliti berupaya memberikan stimulus atau rangsangan 
kepada siswa agar memiliki keterampilan komunikasi. Hal yang dilakukan peneliti adalah mengelompokkan siswa berdasarkan cita-citanya, hal ini dimaksudkan agar siswa dapat mencapai indikator dari disposisi matematik. Beberapa indikator matematik adalah percaya diri dalam mengerjakan tugas, berkomunikasi matematik, menunjukkan rasa ingin tahu dan lain-lain. Melalui keterlibatan siswa pada pembelajaran ini, siswa dapat meningkatkan kemampuan komunikasi matematik sehingga dapat meningkatkan kemampuan pemecahan masalah.

Berdasarkan latar belakang masalah diatas, maka peneliti merumuskan masalah pada penelitian ini adalah: (1) Apakah banyaknya siswa yang mencapai KKM pada hasil belajar matematika dengan model PBL disertai disposisi matematik lebih dari 75\%? (2) Apakah kemampuan pemecahan masalah siswa dengan menggunakan model PBL disertai disposisi matematik lebih tinggi daripada kemampuan pemecahan masalah siswa dengan menggunakan model pembelajaran ekspositori? (3) Apakah dengan model PBL disertai disposisi matematik, kemampuan pemecahan masalah siswa dapat meningkat? (4) Bagaimana respon siswa terhadap pembelajaran yang telah dilakukan?

\section{METODE PENELITIAN}

Populasi dari penelitian ini adalah siswa kelas X program IPS di SMAN 1 Indramayu yang berjumlah 145 siswa yang terbagi dalam 4 kelas. Populasi ini adalah populasi yang homogen karena penelitian sampel baru boleh dilaksanakan apabila keadaan subyek didalam populasi benar-benar homogen (Arikunto, 2010). Peneliti mengambil sampel pada kelas yang berjumlah sama, yaitu kelas X IPS 3 dan X IPS 4 yang masing-masing berjumlah 37 siswa. Selain itu peneliti mengambil dua kelas tersebut dengan memperhatikan kelas yang diambil memiliki materi yang sama, dengan guru yang sama dan mempunyai kurikulum yang sama. Dengan pengambilan acak, diperoleh kelas X IPS 4 sebagai kelas eksperimen dan kelas X IPS 3 sebagai kelas kontrol. Kelas eksperimen adalah kelas yang diberikan model pembelajaran PBL dengan pendekatan scientific learning bermuatan disposisi matematik, sedangkan kelas kontrol adalah kelas yang menggunakan model pembelajaran yang biasa digunakan oleh guru.

Variabel penelitian (Sugiyono, 2013) adalah segala sesuatu yang berbentuk apa saja yang ditetapkan oleh peneliti untuk dipelajari, sehingga diperoleh informasi tentang hal tersebut, kemudian ditarik kesimpulan. Pada penelitian ini terdapat dua variabel, yaitu 
variabel bebas dan variabel terikat, variabel bebas dari penelitian ini adalah kemampuan komunikasi matematik dan disposisi matematik siswa sedangkan variabel terikat pada penelitian ini adalah kemampuan pemecahan masalah.

Penelitian ini dilakukan kepada dua kelas dengan perlakuan yang berbeda, seperti terlihat pada Tabel 1 (Ruseffendi \& Sanusi, 2001).

Tabel 1. Rancangan Penelitian

\begin{tabular}{cclc}
\hline Grup & Pretest & \multicolumn{1}{c}{ Perlakuan } & Posttest \\
\hline Kelas eksperimen & $\mathrm{O}$ & $\begin{array}{l}\text { Pembelajaran dengan muatan } \\
\text { disposisi matematik }\end{array}$ & $\mathrm{O}$ \\
Kelas Kontrol & $\mathrm{O}$ & $\begin{array}{l}\text { Pembelajaran ekspositori } \\
\text { Tem }\end{array}$ & $\mathrm{O}$ \\
\hline
\end{tabular}

Penelitian ini mengacu pada model pengembangan yang dikembangkann oleh Plomp (Rochmad, 2012). Desain model pengembangaan ini terdiri dari 5 fase, yaitu: 1) fase investigasi awal, 2) fase desain, 3) fase realisasi/konstruksi, 4) fase tes, evaluasi, dan revisi, serta 5) fase implementasi. Tahapan pengembangannya digambarkan dalam bentuk skema seperti Gambar 1.

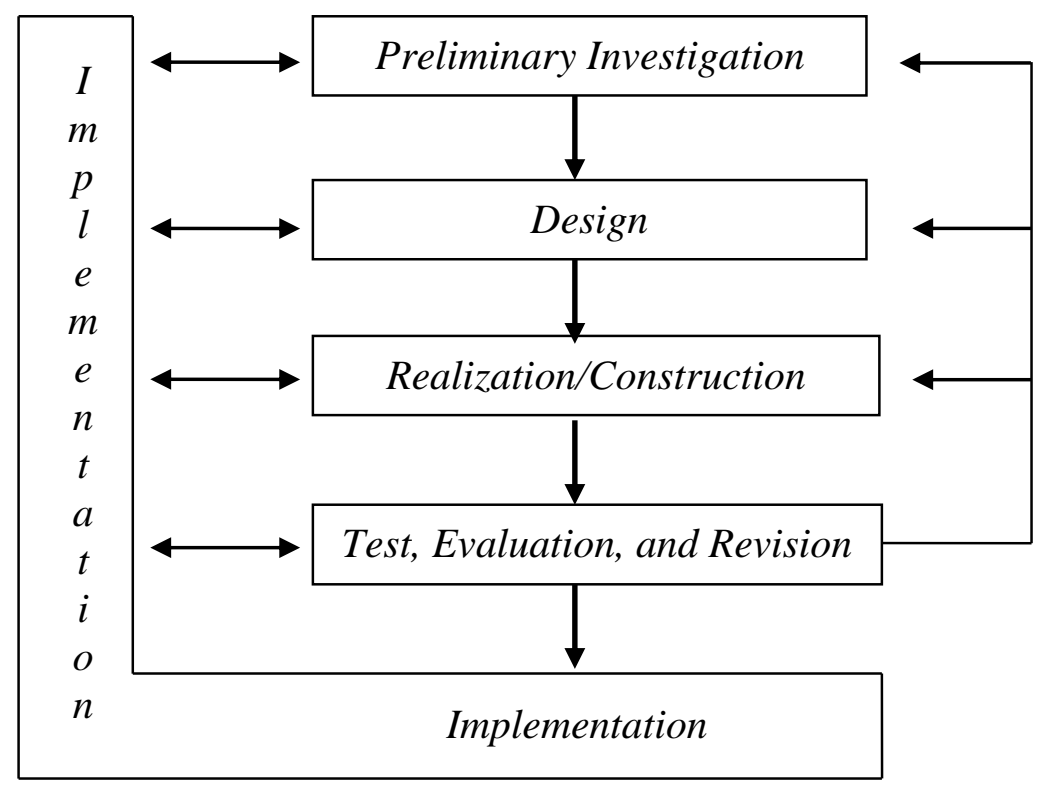

Gambar. 1 Rancangan Penelitian Pengembangan

Model Plomp (Rochmad, 2012) 


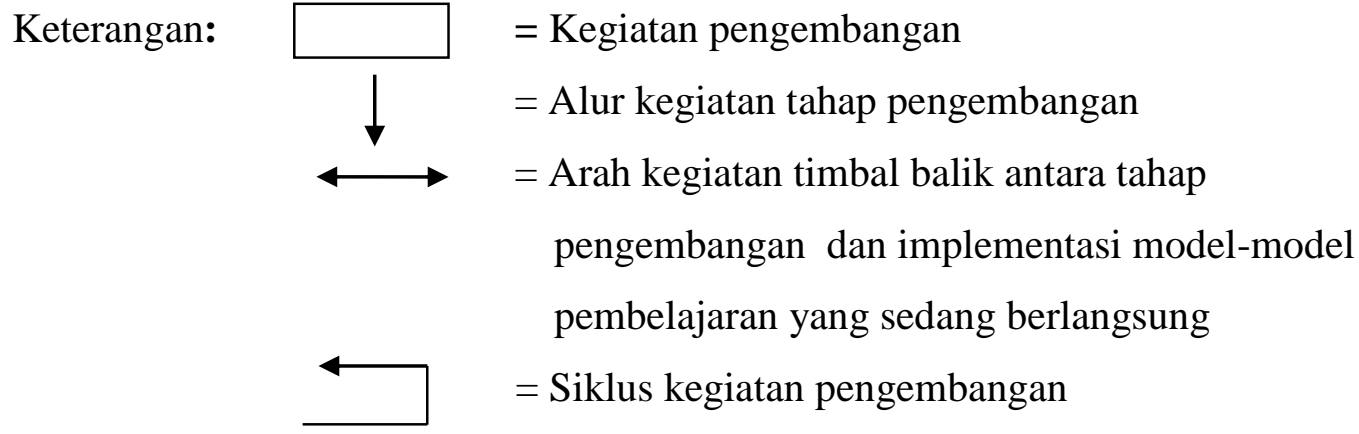

Penelitian diawali dengan investigasi awal, yang sudah dipaparkan pada bab pendahuluan, selanjutnya menguji kehomogenan dari populasi. Kemudian dilakukan pemilihan sample dengan tekhnik random sampling. Setelah terpilih dua kelas yang akan di teliti, dilakukan tes untuk memastikan kedua kelas tersebut mempunyai kemampuan pemecahan masalah yang setara. Selanjutnya peneliti membuat desain perangkat pembelajaran berupa RPP dan lembar soal yang akan diujikan. Setelah perangkat tersebut selesai, maka peneliti melakukan realisasi atau menggunakan perangkat untuk diujikan kepada siswa. Hasil tes tersebut diperoleh pada akhir tiap pertemuan, hasil tes tersebut dianalisis dan dievaluasi, jika hasil masih kurang memuaskan pada kelas eksperimen, maka perlu ada perbaikan pada instrumen yang kurang berhasil. Pada kelas kontrol diberikan perlakuan pembelajaran ekspositori. Hasil tes di analisa dengan menggunakan uji normalitas dan uji proporsi untuk mengetahui apakah banyaknya siswa yang mencapai KKM melebihi 75\%. Selanjutnya di analisa dengan menggunakan uji pengaruh menggunakan SPSS. Analisa selanjutnya adalah menganalisa hasil wawancara siswa pada kelas eksperimen, hal ini dilakukan untuk mengetahui kebenaran pengaruh ketrampilan komunikasi dan disposisi matematik terhadap kemampuan pemecahan masalah. Di samping itu, juga untuk mengevaluasi kekurangan dari penelitian yang telah dilakukan.

\section{HASIL DAN PEMBAHASAN}

Uji normalitas, uji ini dilakukan untuk mengetahui data sampel berdistribusi normal atau tidak. Pengujian dapat dilakukan dengan program SPSS, normalitas suatu data dapat dilihat berdasarkan nilai signifikan (sig) pada kolom Kolmogorof-Smirnov (Sukestiyarno, 2012). Jika nilai sig $>0,05$ maka data berdistribusi normal. Hasil uji normalitas dapat dilihat pada Tabel 2. 
Tabel 2. Hasil Uji Normalitas Pretes

\section{Tests of Normality}

\begin{tabular}{lrrrrrrr}
\hline & \multicolumn{3}{c}{ Kolmogorov-Smirnov $^{\text {a }}$} & \multicolumn{3}{c}{ Shapiro-Wilk } \\
\hline \multirow{2}{*}{ Pretes } & Statistic & Df & Sig. & Statistic & df & \multicolumn{1}{c}{ Sig. } \\
\hline & .069 & & 74 & $\mathbf{. 2 0 0}^{*}$ & .971 & 74 & .084 \\
\hline
\end{tabular}

a. Lilliefors Significance Correction

*. This is a lower bound of the truesignificance.

Berdasarkan Tabel 2, nilai sig $=0,200=20 \%$ akibatnya sig $>5 \%$. Dengan demikian $H_{0}$ diterima, artinya kedua kelas berdistribusi normal sehingga asumsi normalitas terpenuhi.

Uji homogenitas, uji ini dilakukan untuk mengetahui data sampel homogen atau tidak. Pengujian dapat dilakukan dengan program SPSS, homogenitas suatu data dapat dilihat berdasarkan nilai signifikan (sig) pada kolom Levene statistic. Jika nilai sig $>0,05$ maka data homogen. Hasil uji homogenitas pretes dapat dilihat pada Tabel 3.

Tabel 3. Homogenitas Pretes

\section{Independent Samples Test}

Levene's Test for Equality of Variances

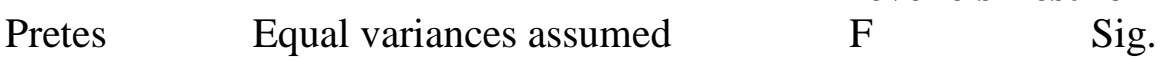

Equal variances not assumed $\quad 1.749 \quad .190$

Berdasarkan Tabel 3, nilai sig $=0,190=19 \%$ akibatnya sig $>5 \%$. Dengan demikian $H_{0}$ diterima, artinya artinya varian kedua populasi homogen.

Uji normalitas, uji ini dilakukan untuk mengetahui data sample berdistribusi normal atau tidak. Pengujian dapat dilakukan dengan program SPSS, normalitas suatu data dapat dilihat berdasarkan nilai signifikan (sig) pada kolom Kolmogorof-Smirnov (Sukestiyarno, 2012). Jika nilai sig $>0,05$ maka data berdistribusi normal. Hasil uji normalitas dapat dilihat pada Tabel 4.

Tabel 4. Normalitas Postes

\begin{tabular}{|c|c|c|c|c|c|c|}
\hline & \multicolumn{3}{|c|}{ Kolmogorov-Smirnov ${ }^{a}$} & \multicolumn{3}{|c|}{ Shapiro-Wilk } \\
\hline & Statistic & df & Sig. & Statistic & $\mathrm{df}$ & Sig. \\
\hline Postes & .090 & 74 & $.200^{*}$ & .988 & 74 & .701 \\
\hline
\end{tabular}

Berdasarkan Tabel 4, nilai sig $=0,200=20 \%$ akibatnya sig $>5 \%$. Dengan demikian $H_{0}$ diterima, artinya kedua kelas berdistribusi normal sehingga asumsi normalitas terpenuhi. 
Uji homogenitas postes, uji ini dilakukan untuk mengetahui data sample homogen atau tidak. Pengujian dapat dilakukan dengan program SPSS, homogenitas suatu data dapat dilihat berdasarkan nilai signifikan (sig) pada kolom Levene statistic. Jika nilai sig $>0,05$ maka data homogen. Hasil uji homogenitas postes dapat dilihat pada Tabel 5.

Tabel 5. Homogenitas Postes

\section{Independent Samples Test}

\begin{tabular}{llll}
\hline \multirow{2}{*}{ Pretes } & & \multicolumn{2}{c}{ Levene's Test for Equality of Variances } \\
& Equal variances assumed & F & Sig. \\
& Equal variances not assumed & 3.469 & .067 \\
\hline
\end{tabular}

Berdasarkan Tabel 5, nilai sig $=0,067=6,7 \%$ akibatnya sig $>5 \%$. Dengan demikian $H_{0}$ diterima, artinya artinya varian kedua populasi homogen.

Uji ketuntasan ini dilakukan untuk mengetahui ketuntasan proporsi dari kelas yang telah dikenai pembelajaran bermuatan disposisi matematik, dari hasil postes siswa, rata-rata dari kelas eksperimen adalah 80,06, sedangkan simpangan bakunya adalah s = 1,916625, dengan jumlah siswa sebanyak $\mathrm{n}=37$, dan rata-rata nilai lebih dari KKM yang ditetapkan adalah $\mu_{o}=78$, menghasilkan nilai $\mathrm{t}=6.53772$ dengan menggunkan rumus dibawah ini.

$$
t=\frac{\bar{x}-\mu_{o}}{\frac{s}{\sqrt{n}}}
$$

Uji ketuntasan klasikal dari kemampuan pemecahan masalah digunakan untuk mengetahui keberhasilan siswa di kelas bermuatan disposisi matematik dalam mencapai ketuntasan belajar mencapai $75 \%$

Rumusan hipotesis:

$\mathrm{H}_{0}: \pi \leq 75 \%$, proporsi siswa di kelas bermuatan disposisi matematik yang mencapai KKM belum melampaui $75 \%$.

$\mathrm{H}_{1}:>75 \%$, proporsi siswa di kelas bermuatan disposisi matematik yang mencapai KKM telah melampaui $75 \%$.

Rumus yang digunakan : $Z=\frac{\frac{x}{n}-\pi_{0}}{\sqrt{\frac{\pi_{0}\left(1-\pi_{0}\right)}{n}}} \quad$ (Sudjana, 2005)

Keterangan :

$\frac{x}{n}=$ proporsi sampel ( $\mathrm{x}$ : banyaknya siswa yang mendapat nilai $\geq 78$ ) 
$z$ : nilai statistik hasil perhitungan

Selanjutnya hasil tersebut dibandingkan dengan nilai z tabel dengan kriteria pengujian 5\%. Jika $Z_{\text {hitung }}>Z_{(0,5-\alpha)}$ maka $\mathrm{H}_{0}$ ditolak akibatnya $\mathrm{H}_{1}$ diterima, artinya ketuntasan klasikal melampuai $75 \%$. Dengan $\mathrm{n}=37, \pi_{0}=0,75$, dan $x=33$, diperoleh nilai $\mathrm{Z}$ hitung sebesar 1,99311. Dengan melihat taraf signifikan 5\% maka diperoleh $z_{\alpha}=z_{0,05}=0,1736$. Terlihat nilai $z_{\text {hitung }}>z_{\text {tabel }}$ atau $1,99311>0,1736$. Dengan demikian $H_{0}$ ditolak atau menerima $H_{1}$ artinya ketuntasan belajar secara klasikal pada proporsi siswa dengan pembelajaran bermuatan disposisi matematik yang mendapat nilai $\geq 78$ sebanyak lebih dari $75 \%$. Selanjutnya menghitung proporsi siswa yang mencapai nilai $\geq 78$. Proporsi $=\frac{x}{n} \times$ $100 \%=\frac{33}{37} \times 100 \%=89,1 \%$ Berdasarkan hasil tersebut, maka kelas yang dikenai pembelajaran bermuatan disposisi matematik tuntas secara klasikal. Uji beda rata-rata, uji banding ini digunakan untuk membandingkan rata-rata kemampuan antara nilai kelas pembelajaran biasa dengan nilai kelas bermuatan disposisi matematik. Uji banding dalam penelitian ini dilakukan dengan menggunakan program SPSS yaitu Independent T-Test. Data yang digunakan adalah data postes dari nilai kelas pembelajaran biasa dengan nilai kelas bermuatan disposisi matematik. Dapat dilihat pada Tabel 6.

Tabel 6. Uji Beda Rata-Rata Kelas Kontrol dengan Kelas Eksperimen

\section{Levene's Test \\ for Equality of \\ Variances}

\begin{tabular}{|c|c|c|c|c|c|c|c|c|c|c|}
\hline & & \multirow[b]{2}{*}{$\mathbf{F}$} & \multirow[b]{2}{*}{ Sig. } & \multirow[b]{2}{*}{$\mathbf{T}$} & \multirow[b]{2}{*}{ Df } & \multirow{2}{*}{$\begin{array}{l}\text { Sig. }(2- \\
\text { tailed) }\end{array}$} & \multirow{2}{*}{$\begin{array}{c}\text { Mean } \\
\text { Difference }\end{array}$} & \multirow{2}{*}{$\begin{array}{l}\text { Std. Error } \\
\text { Difference }\end{array}$} & \multicolumn{2}{|c|}{$\begin{array}{l}\text { 95\% Confidence } \\
\text { Interval of the } \\
\text { Difference } \\
\end{array}$} \\
\hline & & & & & & & & & Lower & Upper \\
\hline \multirow[t]{2}{*}{ Postes } & $\begin{array}{l}\text { Equal variances } \\
\text { assumed }\end{array}$ & 3.469 & .067 & 3.003 & 72 & .004 & 1.17297 & .39055 & .39442 & 1.95153 \\
\hline & $\begin{array}{l}\text { Equal variances } \\
\text { not assumed }\end{array}$ & & & 3.003 & 65.990 & .004 & 1.17297 & .39055 & .39321 & 1.95274 \\
\hline
\end{tabular}

Hipotesis yang digunakan adalah sebagai berikut:

$H_{o}: \mu_{1} \leq \mu_{2}$ (rataan kemampuan pemecahan masalah siswa di kelas bermuatan disposisi matematik lebih kecil atau sama dengan rataan kemampuan pemecahan masalah di kelas dengan pembelajaran biasa). 
$H_{1}: \mu_{1}>\mu_{2} \quad$ (rataan kemampuan pemecahan masalah siswa di kelas bermuatan disposisi matematik lebih besar dari rataan kemampuan pemecahan masalah di kelas dengan pembelajaran biasa).

Berdasarkan output hasil independent sampel test pada baris equal variance assumed diperoleh nilai $t=3,003$ dengan derajat kebebasan $(d f)=72$. Dengan taraf signifikan $5 \%$ diperoleh $t_{\text {tabel }}=t_{(59,0,05)}=1,671$. Terlihat jelas bahwa nilai $t_{\text {hitung }}>t_{\text {tabel }}$ atau 3,003 > 1,671. Dengan demikian, $H_{0}$ ditolak yang berarti rataan kemampuan pemecahan masalah siswa di kelas bermuatan disposisi matematik lebih besar dari rataan kemampuan pemecahan masalah di kelas dengan pembelajaran biasa.

Uji pengaruh untuk menguji besarnya pengaruh disposisi matematik siswa dan keterampilan komunikasi matematik siswa terhadap kemampuan pemecahan masalah siswa. Uji pengaruh juga dapat dilakukan dengan menggunakan program SPSS yaitu Uji Regresi (Sukestiyarno, 2012). Untuk melakukan uji pengaruh digunakan uji regresi ganda dengan hipotesis sebagai berikut. Hipotesis:

$H_{0}: \beta=0$ (Tidak ada pengaruh linier keterampilan komunikasi dan disposisi matematik terhadap kemampuan pemecahan masalah matematik).

$H_{1}: \beta \neq 0$ (ada pengaruh linier keterampilan komunikasi dan disposisi matematik terhadap kemampuan pemecahan masalah matematik), dimana $\beta=\left(\begin{array}{l}b \\ c\end{array}\right)$. Hasil dari uji pengaruh dapat dilihat pada Tabel 7.

Tabel 7. Uji Pengaruh Disposisi Matematik dan Keterampilan Komunikasi Matematik terhadap Kemampuan Pemecahan Masalah

\begin{tabular}{|c|c|c|c|c|c|c|}
\hline \multirow{2}{*}{ Model } & \multicolumn{6}{|c|}{ ANOVA $^{b}$} \\
\hline & & Sum of Squares & Df & Mean Square & $\mathbf{F}$ & Sig. \\
\hline & 1 Regression & 122.861 & 2 & 61.430 & 222.578 & $.000^{\mathrm{a}}$ \\
\hline & Residual & 9.384 & 34 & .276 & & \\
\hline & Total & 132.244 & 36 & & & \\
\hline
\end{tabular}

a. Predictors: (Constant), ktrmpl, dipssi

b. Dependent Variable: postes

Dari Tabel 7 diperoleh nilai $F=222,578$ dan nilai signifikannya adalah 0,000 = $0 \%<5 \%$. Ini berarti disimpulkan bahwa ada pengaruh linier disposisi matematik dan keterampilan komunikasi matematik terhadap kemampuan pemecahan masalah. 
Untuk mengetahui besarnya koefisien dan persamaan regresi dari disposisi matematik, keterampilan komunikasi matematik dan kemampuan pemecahan masalah dilihat di output SPSS. Koefisien regresi terlihat pada Tabel 8.

Tabel 8. Output koefisien Persamaan Regresi

\section{Coefficients $^{\mathrm{a}}$}

\begin{tabular}{lrrrrr}
\hline \multicolumn{7}{c}{ Unstandardized Coefficients } & $\begin{array}{c}\text { Standardized } \\
\text { Coefficients }\end{array}$ & & \\
Model & \multicolumn{1}{c}{ B } & Std. Error & Beta & \multicolumn{1}{c}{ t } & \multicolumn{1}{c}{ Sig. } \\
\hline (Constant) & 562.966 & 33.620 & & 16.745 & .000 \\
Dipssi & -6.654 & .459 & -2.636 & -14.493 & .000 \\
Ktrmpl & .380 & .021 & 3.252 & 17.879 & .000 \\
\multicolumn{2}{c}{ a. Dependent Variable: postes } & & & & \\
\hline
\end{tabular}

Dapat dilihat dari Tabel 8 bahwa sig dari disposisi matematik dan keterampilan komunikasi matematik adalah $0 \%$ lebih kecil dari $\alpha=5 \%$, artinya disposisi matematik dan keterampilan komunikasi matematik sama-sama berpengaruh positif terhadap kemampuan pemecahan masalah siswa. Persamaan regresinya adalah $\hat{Y}=562,966-6,654 X_{1}+$ $49,163 X_{2}$. Dengan demikian dapat diketahui bahwa besarnya pengaruh disposisi matematik dan keterampilan komunikasi matematik sebesar 0.929. Hal ini berarti bahwa disposisi matematik dan ketrampilan komunikasi matematik sangat diperlukan untuk meningkatkan kemampuan pemecahan masalah pada siswa.

Hasil wawancara dengan siswa sebanyak 37 siswa pada kelas eksperimen, terdapat kelebihan dan kekurangan dalam penelitian ini. Kelebihan dari model pembelajaran ini adalah 30 dari 37 siswa menyatakan pembelajaran pada materi trigonometri menarik, 37dari 37 siswa menyatakan guru dapat membuat sikap siswa lebih baik, terutama kejujuran dan sikap tekun. 26 dari 37 siswa menyatakan ada perubahan sikap pada diri mereka. 10 dari 37 siswa menyatakan belum percaya diri ketika mempresentasikan hasil pekerjaannya, 32 dari 37 siswa menyatakan pembelajaran dengan model ini bermanfaat bagi siswa, dan lain lain yang bila dirata-rata, pembelajaran dengan muatan disposisi metamatik dan keterampilan komunikasi matematik dapat membantu siswa meningkatkan kemampuan pemecahan masalah sisiwa. 


\section{KESIMPULAN}

Kesimpulan dari penelitian ini adalah sebagai berikut.

1. Banyaknya siswa yang mencapai KKM lebih dari $75 \%$

2. Kemampuan pemecahan masalah kelas bermuatan disposisi matematik lebih baik dari pada kelas dengan pembelajaran biasa

3. Model PBL disertai disposisi matematik kemampuan pemecahan masalah siswa dapat meningkat.

4. Siswa merespon positif terhadap pembelajaran dengan menggunakan model PBL disertai disposisi matematik.

Saran yang peneliti rekomendasikan adalah rasa percaya diri siswa pada penelitian ini masih kurang, sehingga dalam penelitian selanjutnya, peneliti lebih memperhatikan sikap percaya diri dari siswa. Selain itu diskusi juga perlu diperbaiki untuk meningkatkan pemahaman konsep diperlukan untuk meningkatkan pemecahan masalah siswa.

\section{DAFTAR PUSTAKA}

Arikunto, S. (2010). Prosedur Penelitian Suatu Pendekatan Praktik. Jakarta: PT. Rineka Cipta.

Bell. (2013). Uptake as a Mechanism to Promote Student Learning. International Journal of Education in Mathematic, Science and Technology. Vol. 1(4), p.217-229.

Elida, N. (2012). Meningkatkan Kemampuan Komunikasi Matematika Siswa Sekolah Menengah Pertama Melalui Pembelajaran Think-Talk-Write (TTW). Jurnal Ilmiah Program Studi Matematik STKIP Siliwangi Bandung. Vol. 1(2), p.178-185.

Hudojo, H. (1988). Mengajar Belajar Matematika. Jakarta: Depdikbud.

Kemendikbud. (2013). Model Pembelajaran Problem Based Learning (PBL). Jakarta: Kemendikbud.

Rochmad. (2012). Pembelajaran Matematika Konstruktivistik Pola Pikir Induktif-Deduktif. Semarang: UNNES.

Ruseffendi \& Sanusi, A. (2001). Dasar-Dasar Penelitian dan Non-Eksata Lain-nya. Semarang: Unnes Press.

Sugiyono. (2013). Metode Penelitian Pendidikan. Bandung: CV. Alfabeta.

Sukestiyarno. (2012). Olah Data Penelitian Berbantuan SPSS. Semarang: UNNES.

Wichelt \& Kearney. (2009). Communication: A Vital Skill of Mathematics. Action Research Project. Paper 18. University of Nebraska-Lincoln. 